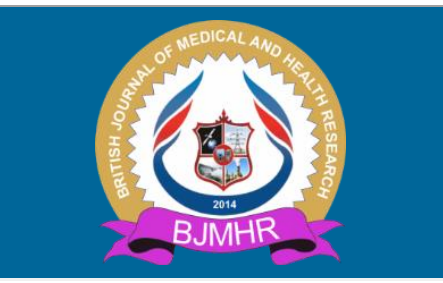

\title{
BJMHR
}

British Journal of Medical and Health Research

Journal home page: www.bjmhr.com

\section{Studies On the Pharmacognostic Profiling And Anticonvulsant Activity Of Morinda lucida Leaves Benth (Rubiaceae)}

Odoh, Uchenna Estella*1, Okwoli, Dorothy Atteh ${ }^{\mathbf{1}}$, Osuala, Felix Ngozi ${ }^{2}$

1.Department of Pharmacognosy and Environmental Medicines, Faculty of Pharmaceutical Sciences, University of Nigeria, Nsukka, Nigeria

2.Department of Pharmacognosy, Faculty of Pharmaceutical Sciences, Madonna University, Elele, Rivers State, Nigeria

\section{ABSTRACT}

The anticonvulsant activity of the methanol extract of Morinda lucida, a tropical shrub which have shown great medicinal value was evaluated using the suppression test against pentylenetetrazole (PTZ) and isoniazid (INH) induced convulsion. The pharmacognostic and acute toxicity studies were also carried out. This research is to evaluate anticonvulsant effectiveness in line with one of its ethnomedicinal use and also to establish the standards for the leaf for proper identification as well as its safety margin. The extract at the studied doses $(200,400$ and $800 \mathrm{mg} / \mathrm{kg}$ ) showed a significant dose-dependent delay of the time of onset, peak of seizure, recovery and mortality from seizure. The percentage animal survival for PTZ- induced convulsion for 200, 400 and $800 \mathrm{mg} / \mathrm{kg}$ extract is 60,40 and $60 \%$ while diazepam (standard drug) gave $100 \%$. INH -induced convulsion also showed a significant delay as the dose increase for the time of onset, peak of seizure and mortality but there was no recovery for all the dose of extract used but $800 \mathrm{mg}$ of the extract gave a significant delay in peak of seizure from the onset that was more than the peak of seizure of the standard drug (diazepam) used. The anticonvulsant activity of M. lucida may be attributed to the presence of alkaloids, flavonoids, saponins, steroids, terpenoids and tannins, which have been found in phytochemical investigation of the methanol extract of the plant. The acute toxicity test on the crude extract showed no toxic effect at the higher dose of $5000 \mathrm{mg} / \mathrm{kg}$ which indicate the safety of the extract. The data obtained from pharmacognostic studies gave 11.00, 8.5, 1.00, 2.00, 6.50, 6.00 and $3.40 \%$ of moisture content, total ash value, acid insoluble ash, water soluble ash, water soluble extractive and alcohol soluble extractive yield respectively. From the study, it shows that Morinda lucida do possess anticonvulsant activity and justifies its use in folkloric medicine. The pharmacognostic features can be used in the standardization of $M$. lucida for proper identification of the plant and for possible inclusion in the Pharmacopoeia.

Keywords: Morinda lucida, Phytochemical analysis, Pharmacognostic analysis, Acute toxicity, Anticonvulsant 


\section{INTRODUCTION}

Epilepsy is one of the most common and extensive neurological disorders in the human population [1]. Convulsion, epilepsy and seizure differ in their meaning but most authors used them interchangeably. Epilepsy can affect all ages [2;3], unlike convulsion, it stays after a child is even above five years. Convulsion occurs when there is rapidly, uncontrollable and involuntary contraction and relaxation of the muscles of the body. Seizures are induced mainly due to imbalance between inhibitory and excitatory neurotransmitters [4]. Epilepsy is a clinical condition characterized by the occurrence of spontaneous seizures induced by a complex of neurotransmitter systems [5]. It can also be defined as a clinical syndrome brought about by over activity of irritated brain cells and characterized by partial or complete loss of consciousness and muscular spasm (convulsion) [6]. Seizure and convulsion are said to occur in epileptic crises. Most epileptic syndromes contain particular neurophysiological and clinical characteristics, the seizures being the result of abnormal, hyperactive, or hypersynchronous neuronal discharges [7]. Not all seizures are characterized by convulsion and also not all seizures are epileptic, for example, febrile seizure which can lead to convulsion especially in feverish condition. Other possible causes of convulsions that are not due to epilepsy include meningitis, drug or alcohol abuse, poisoning, hypoglycemia and so on. In Africa, epilepsy has always been poorly understood by society and has frequently been associated with numerous myths and beliefs [8; 9]. Among the 50 million people with epilepsy in the world, approximately $80 \%$ of them live in developing countries of which 10 million people are in Africa alone $[10 ; 11]$. Despite an increasing number and variety of antiepileptic drugs (AEDs), many refractory cases of epilepsy still remain highly resistant to AED treatment $[12 ; 13]$. Moreover, the current therapy of epilepsy with modern antiepileptic drugs is associated with side effects, including chronic toxicity and adverse effects on cognition $[14 ; 15]$. Due to the limited availability of affordable conventional pharmaceutical medicines in many tropical countries, about $80 \%$ of the African rural population is using the complementary and alternative medicine $[16 ; 17]$. The frequency of epilepsy, coupled with inaccessibility of some antiepileptic, makes it a major public health problem in developing countries $[18 ; 11]$. Alternative medicine has been a source of therapy for the treatment of epilepsy. Many plants has been reported to possesses anticonvulsant activity; Alstonia scholaris [19], Premna corymbosa [20], Nylandtia spinosa [21], Holoptelea Integrifoila [22], Homalium letestui [23], Annona senegalensis [24], Cymbopogon Winterianus [25], Pongamia Pinnata [26] etc.

Morinda lucida Benth (Rubiaceae) is a tropical West African tree commonly known as the Brimstone tree. Amongst the Igbo (South-East Nigeria), it is locally known as "Huka", 
"Eze-ogu" [27] and Nfia in Igbo [28] and Oruwo or ruwa among the Yoruba tribe [29; 30; 31], Ogele in Igalaland (middle belt; Kogi state, Nigeria). It is known as Sangogo or Bondoukuo alongua (Cote d'Ivoire), Ewe amake (Ghana), Ewe amaka or Atak ake (Togo). M. lucida is of medium-size about $18-25 \mathrm{~m}$ tall, the bark is grey to brown in colour, $\mathrm{s}$ are white in colour, the fruit is a drupe, seed is ellipsoid, yellowish and soft [32]. It is an evergreen shrub with crooked or gnarled bole and branches; bark smooth to roughly scaly, grey to brown, often with some distinct purple layers [33]. Different part of this plant is employed for different medicinal purpose in many country and its said to have a high efficacy and potency. Cold decoction of the plant leaves is used for the treatment of fever in Southern Cameroon [29\} and the decoction of its bark is employed in Cameroun for treatment of diabetes [33]. It is also used in most parts of West Africa, the bitter water decoction of the plant bark, root and leaf are used as bitter tonic and as astringent for dysentery, abdominal colic, intestinal worm infestation and decoction of the plant root or stem to make "bitters" sometimes by the Europeans [29]. It is of great medicinal value as it is widely used by the people of Igala Kingdom against stomach aches and convulsions (especially in children). Much work has been done on its numerous medicinal properties. The leaves are used as "oral teas", which are usually taken orally for the traditional treatment of malaria, and as a general febrifuge, analgesic, laxative and antiinfections [34]. The leaves have also been reported to possess strong trypanocidal and aortic vasorelaxant activities [35]. Further studies have shown that leaf and stem bark of M. lucida posses anticancer [36], hepatoprotective [37], antispermatogenic [38], hypoglycemia and antidiabetic [29] activity. M. lucida is used as an astringent and antiseptic for ulcerating abscess, exudate is rubbed on affected area [39]. Stem bark, roots and leaves infusion is used as an antimalarial [40; 41; 42], toxicity and mutagenic studies [34; 36], antioxidant and reducing activities [43], and anti-microbial activity [44]. The crude ethanolic extract of the leaves is said to contain alkaloids, cardenolides and saponins (Adomi and Umukoro, 2010). From the wood and bark of Morinda lucida 18 anthraquinones, tannins, flavonoids and saponosides have been isolated (Zimudzi and Cardon, 2005). Convulsion is a neuronal disorder that can either be idiopathic or due to an underlying disease which can be tumor or other factor which were earlier stated in the etiology. The purpose of this study is to mainly confirm one of the ethnomedicinal uses of Morinda lucida, the anticonvulsant effectiveness and establish the standards for the leaf that could actually help in the proper identification of the plant.

\section{Taxonomic profile of Morinda lucida Benth}

Kingdom:

Subkingdom:

Superdivision:

Division:
Plantae

Tracheobionta

Spermatophyta

Angiosperms 


$\begin{array}{ll}\text { Class : } & \underline{\text { Eudicots }} \\ \text { Subclass: } & \underline{\text { Asterids }} \\ \text { Order: } & \underline{\underline{\text { Gentianales }}} \\ \text { Family: } & \underline{\text { Rubiaceae }} \\ \text { Subfamily: } & \underline{\text { Rubioideae }} \\ \text { Tribe: } & \underline{\text { Morindeae }} \\ \text { Genus: } & \text { Morinda } \\ \text { Species: } & \text { lucida } \\ \text { Scientific name: } & \text { Morinda lucida, Benth. }\end{array}$

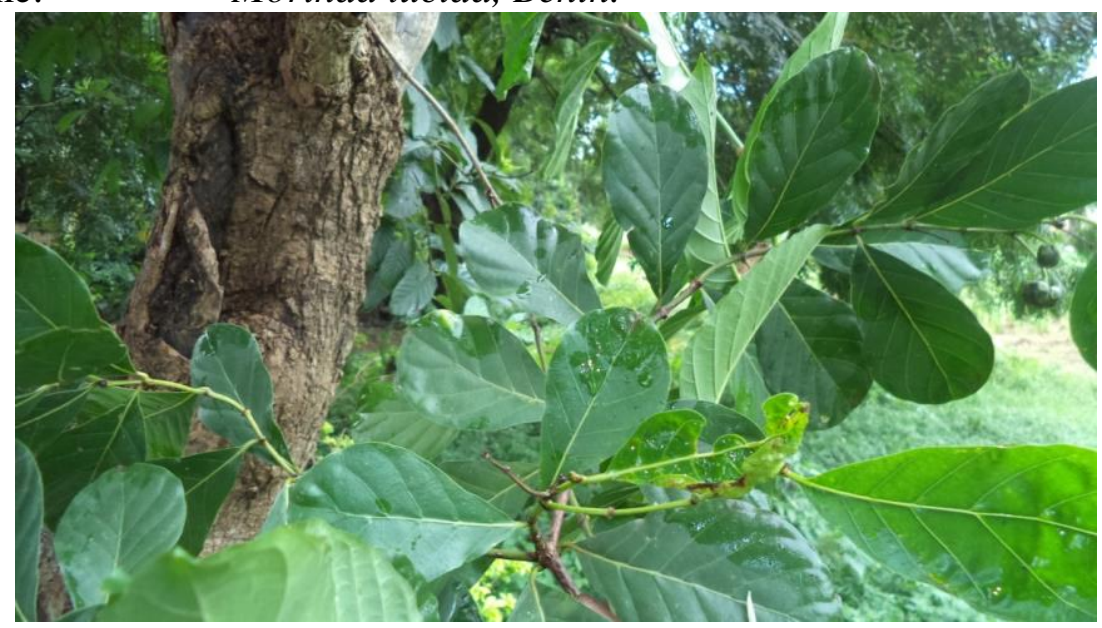

Figure 1: Photograph of Morinda lucida tree.

\section{MATERIALS AND METHOD}

\section{Collections and identification}

The leaves of the plant M. lucida were collected in June at Idah, in Kogi state. The fresh leaves were identified by Mr. A.O, Ozioko of International Centre for Ethnomedicine and Drug Development (InterCEDD), Nsukka.

\section{Preparation of plant material}

The leaves were carefully separated from their stalk and it was dried under the shade because exposure to light impairs the quality and destroys the fragrance of volatile oils (Remington's 1985) and dried to a constant weight. . The samples were pulverized to a coarse powder. This was weighed using Molenschot molen weighing balance.

\section{Animals}

Adult albino mice $(15-40 \mathrm{~g})$ of either sex bred in the animal house of the Department of Pharmacology and Toxicology, University of Nigeria, Nsukka (UNN) were used for the study. The mice were allowed free access to water and food in the animal house for a minimum of seven days before the commencement of the experiment. The mice were fed with the growers feed. They were randomly assigned to different control and treatment groups in the course of the experiments. Approval for the use of animal subjects was secured from the Animal Research Ethics Committee, University of Nigeria, Nsukka. The animals 
were handled according to International protocol for handling laboratory animals as documented in the European Community guideline.

\section{Extraction}

A $500 \mathrm{~g}$ of the powdered leaves of M. lucida were extracted with 2.51 of methanol (analytical grade) in a cold maceration process for $48 \mathrm{~h}$. The extract was filtered, evaporated and the crude methanol extract was preserved for further work.

\section{Preliminary phytochemical tests}

This powdered leaves sample were subjected to phytochemical tests in order to detect the presence or absence of major secondary plant metabolites of pharmacognostic importance which include the following: steroids, alkaloids, saponins, tannins, flavonoids, resins oils, e.t.c. $[45 ; 46]$.

\section{Evaluation of the pharmacognostic standards}

The parameters include the following: the macroscopic and microscopic characteristics. The macroscopic characteristics comprise the organoleptic features (colour, odour, taste), and morphological character (physical appearance, fracture, texture) of the crude drug. The microscopic characters include tissues and cellular components. In microscopy, we have quantitative and qualitative microscopy.

\section{Macroscopic analysis}

The leaves were visually examined. The macroscopic character of the leave which includes the type of margin, petiole, venation, base, and so on were observed and noted. The organoleptic properties like colour, odour and taste of the leaves was also observed and noted.

\section{Microscopic examination of transverse sections}

The staining method as described by Odoh et al., [47] was used. Sledge microtome was used for sectioning of the specimen. The sections were transferred into staining jar and stained in safranin for 5 minutes. The safranins were drained off and were washed about three times with distilled water. Then $97 \%$ alcohol was used to wash the sections twice each. The section were counter-stained in $1 \%$ past green for 5 minutes and washed with absolute alcohol for about three to four times. After that, the section were transferred into a staining jar containing $50 / 50$ alcohol/xylene and washed until they became clear. Finally the pure xylene was used to clear the sections and the balsam mountant was used to mount the sections on the slide.

\section{Microscopy of the powdered leaves}

A needle pinch of the powered crude drug was place on a slide drops of chloral hydrate were added to moisten the powered drug. It was covered with cover slip and passed across the flame of Bunsen burner repeatedly until bubbles occur. Then it was allowed to cool. The slide was viewed under microscope to reveal microscopic characters which were observed and 
noted. For proper clearing, the plant material can be boiled in chloral hydrate in a breaker or test tube [47].

\section{Determination of analytical standards}

\section{Determination of ash values}

The ash content of a crude drug is generally taken to be the residue remaining after incineration. It usually represents the inorganic salts naturally occurring in the drug and adhering to it, but may also include organic matter added for the purpose of adulteration. An ash determination furnishes a basis for judging the identity and cleanliness of a drug and gives information relative to its adulteration with inorganic matter. The methods adopted for the determination of ash values follow the specification given by Odoh et al.,[48] and British Pharmacopoeia [49].

\section{Total Ash Values}

A total ash value represents the amount of the residual substance not volatilized on ignition at $450{ }^{\circ} \mathrm{C}$. It is used to exclude drugs which have been coated with chalk, lime or calcium sulphate to improve the appearance. A tarred nickel crucible was ignited to a constant weight in a dull red heat, cooled and stored in desiccator. $2.0 \mathrm{~g}$ the powdered material was weighed into the nickel crucible and heated gently until all the moisture had been driven off and the material had been completely charred. The heat was increased until most of the carbon was had vaporized, after which the materials were heated to about $450{ }^{\circ} \mathrm{C}$ to make the residue carbon free. The residue was cooled and weighed. The heating and cooling were continued until a constant weight was achieved.

\section{Acid insoluble ash}

The acid insoluble means the ash insoluble in dilute hydrochloric acid and is often not more value than total ash value. Majority of drug contain calcium oxalate, but in variable amounts. A total ash values therefore may vary within wide limits for specimens of genuine drug. Total ash cannot detect the earthly matter(s) adherent a drug. Since calcium oxalate or carbonate yield by the incineration is soluble in hydrochloric acid, one can therefore remove all the ash by means of hydrochloric acid and weighing the residue which is known as acid-insoluble ash. This way, one can obtain evidence of the presence of earthly matter(s), which is likely to occur with leaves that are densely pubescent, clothed or abundant in trichomes or those that tend to retain earthly matter (s) splashed on them during heavy rainfall. The total ash obtained from (a) above was transferred to a beaker containing $25.0 \mathrm{ml}$ of $30 \%$ dilute hydrochloric acid, heated to boiling in a water bath 5 minutes and filtered with an ash less filter paper. Water was used to wash down the paper until it was free from the acid. The filter paper was dried in the oven, folded into a narrow cone, inserted with a weighed starred nickel crucible 
and heated at $150{ }^{\circ} \mathrm{C}$ until it was completely ashed. The residue was then heated more strongly and cooled in a desiccator after which the crucible was reweighed.

\section{Water soluble ash}

This was used to detect the presence of material exhausted by water. The water soluble ash is subjected to a much greater reduction than the total ash and is therefore used as an important indication of the presence of exhausted materials substituted for the genuine article. A nickel crucible was ignited to a constant weight at $450^{\circ} \mathrm{C}$ and reweighed after $2.0 \mathrm{~g}$ of the powdered material had been put into it. The crucible with the drug was ignited at low heat, initially to burn off the carbon content. The heat was gradually increased until all the carbon was burnt off. The crucible was cooled in desiccators. More dilute sulpuric acid was added and heating continued to about $800{ }^{\circ} \mathrm{C}$ with occasional cooling and reweigh until a constant weight was obtained.

\section{Determination of extractive yields}

The determination of alcohol-soluble extractive and water soluble extractive is used as a means of evaluating drugs, the constituents of which are not readily estimated by other means. In some cases, the amount of a drug soluble in given solvent is an index of its purity, the constituents of which are not readily estimated by other means. In some cases, the amount of a drug soluble in a given solvent is an index of its purity. The methods used here are in conformity with the method of Odoh et al., [47] and British Pharmacopoeia [49].

\section{Alcohol soluble extractive}

A $5.0 \mathrm{~g}$ of the powdered plant material was weighed accurately and place in a $250.0 \mathrm{ml}$ stopper conical flask, then $100.0 \mathrm{ml}$ of $90 \%$ alcohol was added. The stopper was firmly replaced and the contents of the flask were shaken mechanically for 6 hours and allowed to macerate for a further 18 hours that is a total of 24 hours and then filtered. $20.0 \mathrm{ml}$ of the filtrate was evaporated to dryness in a $25.0 \mathrm{ml}$ beaker over water bath. The residue was dried to a constant weight at $105^{\circ} \mathrm{C}$ and then weighed.

\section{Water soluble extractive}

A $5.0 \mathrm{~g}$ of the powdered plant material was accurately and placed in a $250 \mathrm{ml}$ stopper conical flask. $100.0 \mathrm{ml}$ of distilled water was added and the stopper was replaced firmly. The content of the flask were shaken mechanically for 6 hours and were allowed to macerate for a further 18 hours that is a total of 24 hours and then filtered. $20.0 \mathrm{ml}$ of the filtrate was evaporated to dryness in a $25.0 \mathrm{ml}$ beaker over a water bath. The residue was dried to a constant weight at $105^{\circ} \mathrm{C}$.

\section{Determination of moisture content}

A tarred evaporating dish was heated to a constant weight and stored in desiccators. $2.0 \mathrm{~g}$ of the powdered plant material was added to the dish kept in an oven maintained at a 
temperature of $105{ }^{\circ} \mathrm{C}$. It was allowed to dry until a constant weight was achieved. The different in weight of the evaporating dish was noted.

\section{In vivo pharmacological studies}

\section{Acute Toxicity and lethality (LDs0)}

The acute toxicity testing was carried out following the procedure outline by Lorke [50] using oral route for drug administration. In the study, the experiment was done in two stages (stages 1 and stages 2). The animal were divided into 2 group 1 comprising of three sets of animal with each set containing three animal while the group two contains a set of four animals. Group one was used for the first stage of the experiment while the group two was used for the second stage of the experiment. A total of 13 albino mice were used for the study.

The animals before they were fed with the testing extract, they were allowed to adapt in their environment for days under condition of free access to food and water. In stage 1, the 3 groups of three mice each were put in a separate cage and their weight in gram noted and recorded. In this stage, the mice were fasted overnight and the extracts in 10, 100, $1000 \mathrm{mg} /$ $\mathrm{kg}$ body weight of the extract(dissolved and diluted using aqueous solvent) each corresponding to dose given to a particular set of animal was orally administered .The animals were monitored for signs of toxicity and death for 24 hours. The results were recorded after 24 hours, which was used as a guide for the second stage of the experiment. In this second stage, 4 groups each containing one mouse $(n=1)$ was given four more specific doses $(1,600,2,900$, and $5000 \mathrm{mg} / \mathrm{kg}$ respectively) of the extract by oral administration based on the result of the first stage. The $\mathrm{LD}_{50}$ value was determined by calculating the geometric mean that caused death and the highest dose for which the animal survived (0/1 and 1/1). This was also observed for 24 hours for deaths and no death was recorded.

\section{Anticonvulsant screening}

\section{Effects of the extract on pentylenetetrazole-induced convulsion}

Twenty-five albino mice were randomly divided into five groups of five animals per group. The group 1 was administered water for injection $(5 \mathrm{ml} / \mathrm{kg} \mathrm{P}$. O), while the group 2 received Diazepam (0.5 mg/kg i.p.) as positive control. The remaining three groups received the crude extract at three doses of 200,400 and $800 \mathrm{mg} / \mathrm{kg}$ respectively. Thirty minutes later, pentylenetetrazole (PTZ) ( $80 \mathrm{mg} / \mathrm{kg}$ i.p) was administered to the entire animal. The time of onset, peak of the tonic-conic seizure as well as percentage death and recovery time were recorded in each group. Animals devoid of seizure/convulsion with subsequent death during the 60 minutes observation period were considered protected [51].

\section{Effects of the extract on isoniazid (INH) -induced seizures method}

Isoniazid (INH) induced seizures test was performed on mice (15-35 g). The mice were injected with water for injection $(5 \mathrm{ml} / \mathrm{kg} \mathrm{p}$. o) for the group 1 , while the group 2 received 
Diazepam (0.5 mg/kg i.p.) as the standard drug and groups 3-5 were administered with 200, 400 and $800 \mathrm{mg} / \mathrm{kg}$ of the test drug p.o respectively. After $30 \mathrm{~min}$, a dose of $250 \mathrm{mg} / \mathrm{kg}$ of INH injection was given i.p. The sequence of seizure latency, seizure duration, recovery time, $\%$ protection and mortality were studied and recorded. Animals exhibiting these seizures pattern were detected.

\section{Statistical analysis}

The results were analyzed using SPSS version 21. ANOVA followed by Dunnett's post-hoc test and all results were presented as means \pm standard error mean (S.E.M.). The mean values of the test groups were compared to those of the control groups and the difference regarded as significant at $\mathrm{p}<0.05$.

\section{RESULTS AND DISCUSSION}

\section{Yield of Extract}

A $500 \mathrm{~g}$ of pulverized dried leaves of Morinda lucida, Benth used for extraction, yielded $70.83 \mathrm{~g}(14.17 \%)$ of solid mass after evaporation of the methanol.

\section{Phytochemical analysis}

The phytochemical analysis of the crude methanol extract of $M$. lucida showed that it contains the alkaloids, glycosides, reducing sugar, flavonoids, resins, carbohydrates, steroids, terpenoids, tannins, saponins, though to varying degrees. The phytochemical constituents of the extract were shown in the Table 1.

Table 1: Phytochemical constituents of the methanol leaf extract of Morinda lucida

\begin{tabular}{ll}
\hline Constituents & Inference \\
\hline Carbohydrates & + \\
Reducing sugars & + \\
Alkaloids & + \\
Glycosides & + \\
Saponins & + \\
Tannins & + \\
Flavonoids & + \\
Resins & + \\
Proteins & + \\
Oils & - \\
Steroids & + \\
Terpenoids & + \\
\hline
\end{tabular}

Key:

- = Absent,

$+=$ Present

Pharmacognostic standards

Structural Standard

Macroscopic examination 
The leaf lamina is compound, pinnate and oppositely arranged. The leaf is deeply greenish in colour, the upper surface is shiny and it also has continuous network of veins. The leaf is ovate in shape with acuminate apex and the margin is entire. The leaf base is cuneate.

\section{Microscopic examination of transverse sections}

Section of the transverse sections of Morinda lucida showed upper and lower epidermis with the lower epidermis having anomocytic stomata and trichomes. This is followed by numerous palisade cells and acicular calcium oxalates. The section also showed spiral xylem vessels and phloem parenchyma with short papillose trichomes (Figure 2- 7).

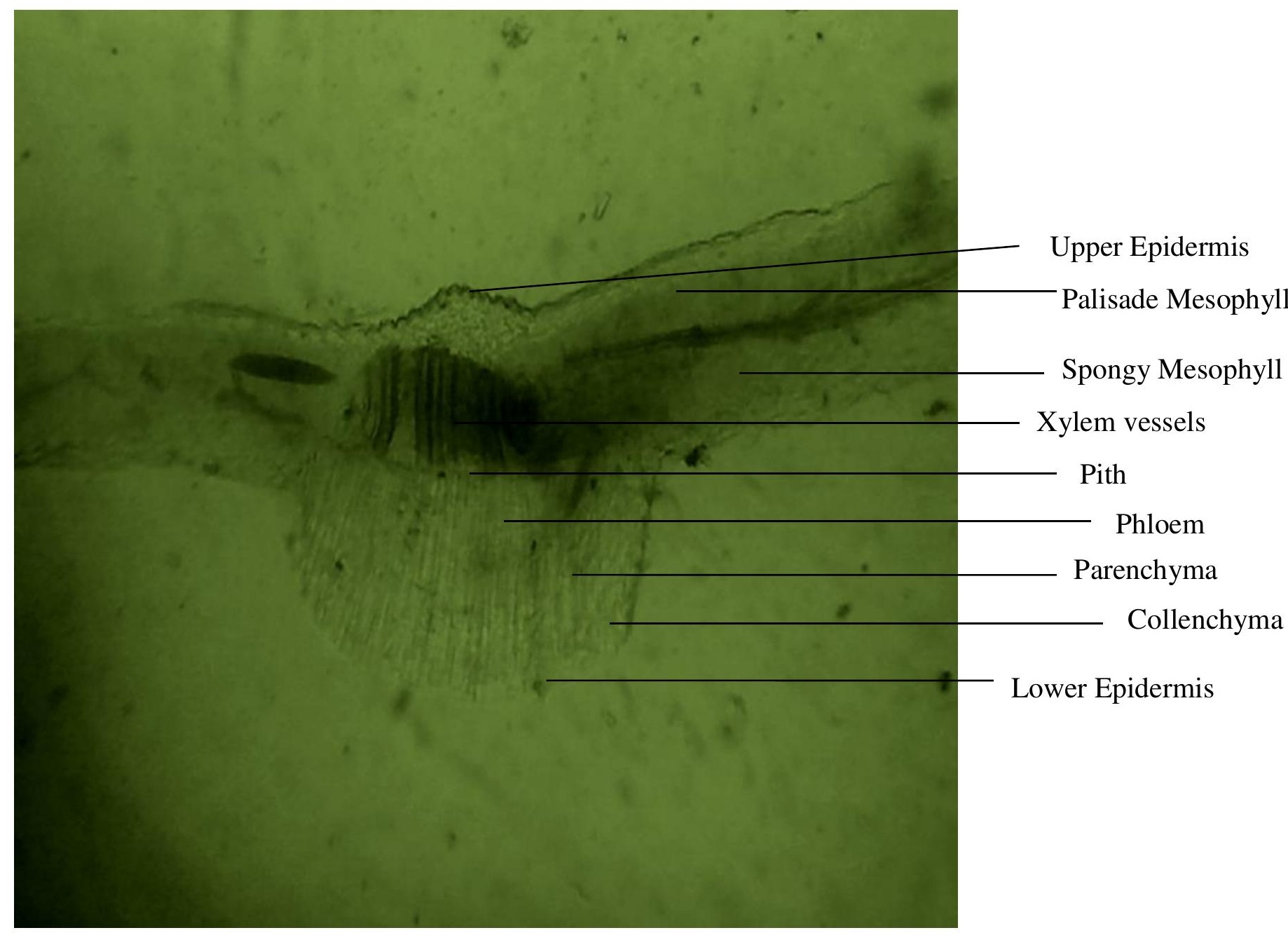

Figure 2: Photomicrograph showing the transverse section of leaf of Morinda lucida $\mathbf{x}$ 100. 


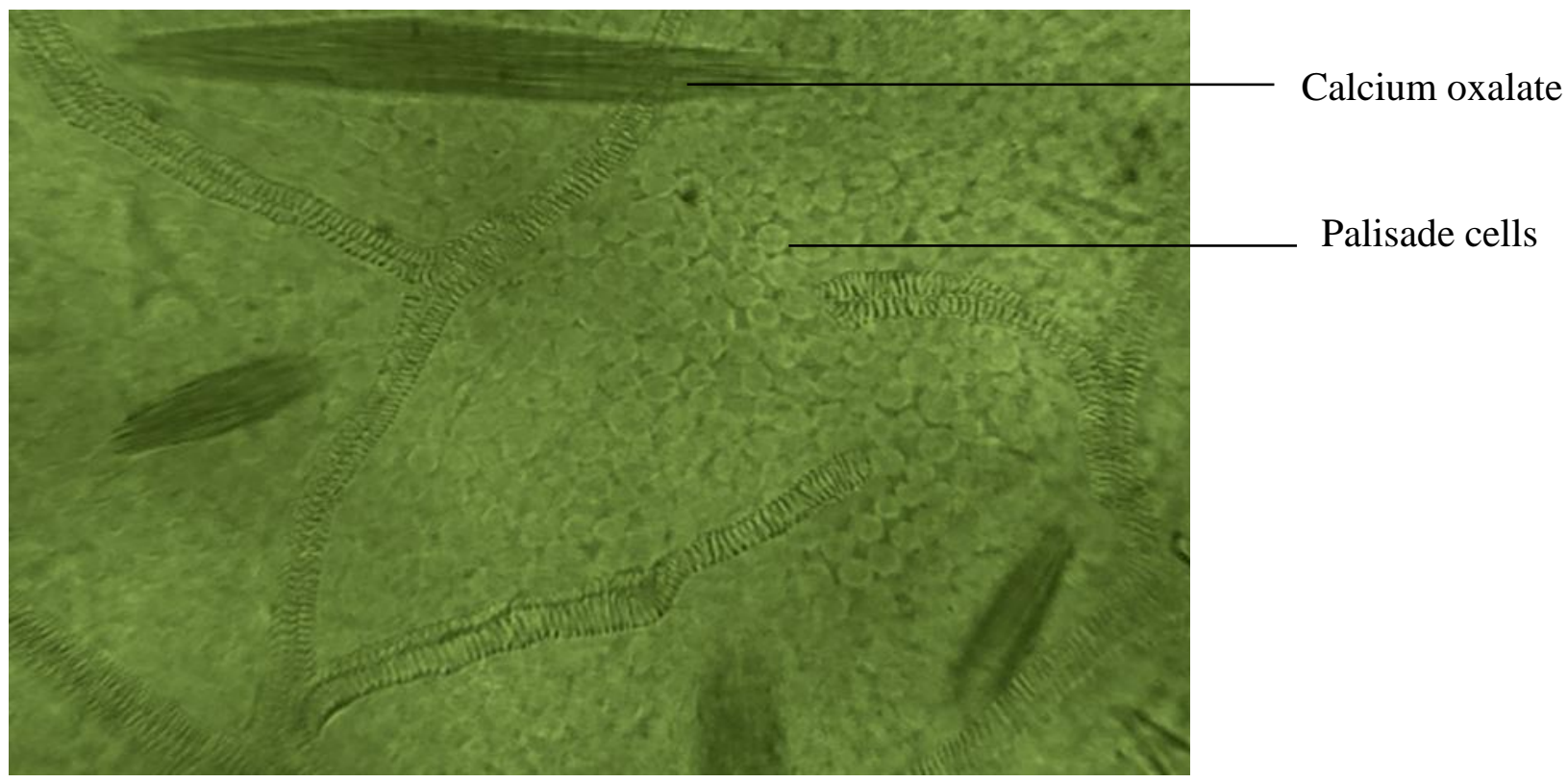

Figure 3: Photomicrograph of the sectional view of the transverse section of Morinda lucida showing palisade cells and acicular calcium oxalates

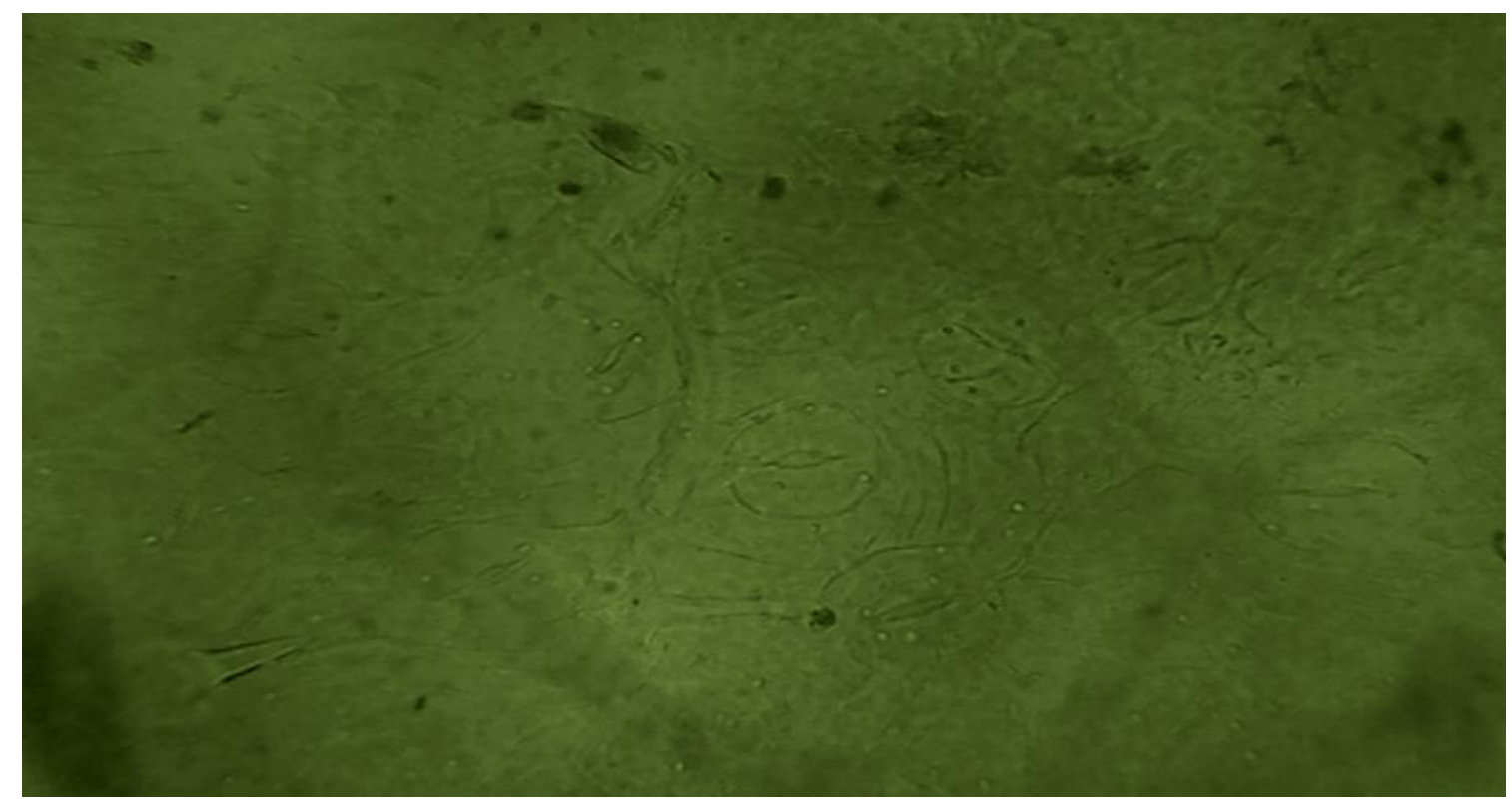

Figure 4: Photomicrograph of the sectional view of the transverse section of Morinda lucida showing anomocytic stomata 


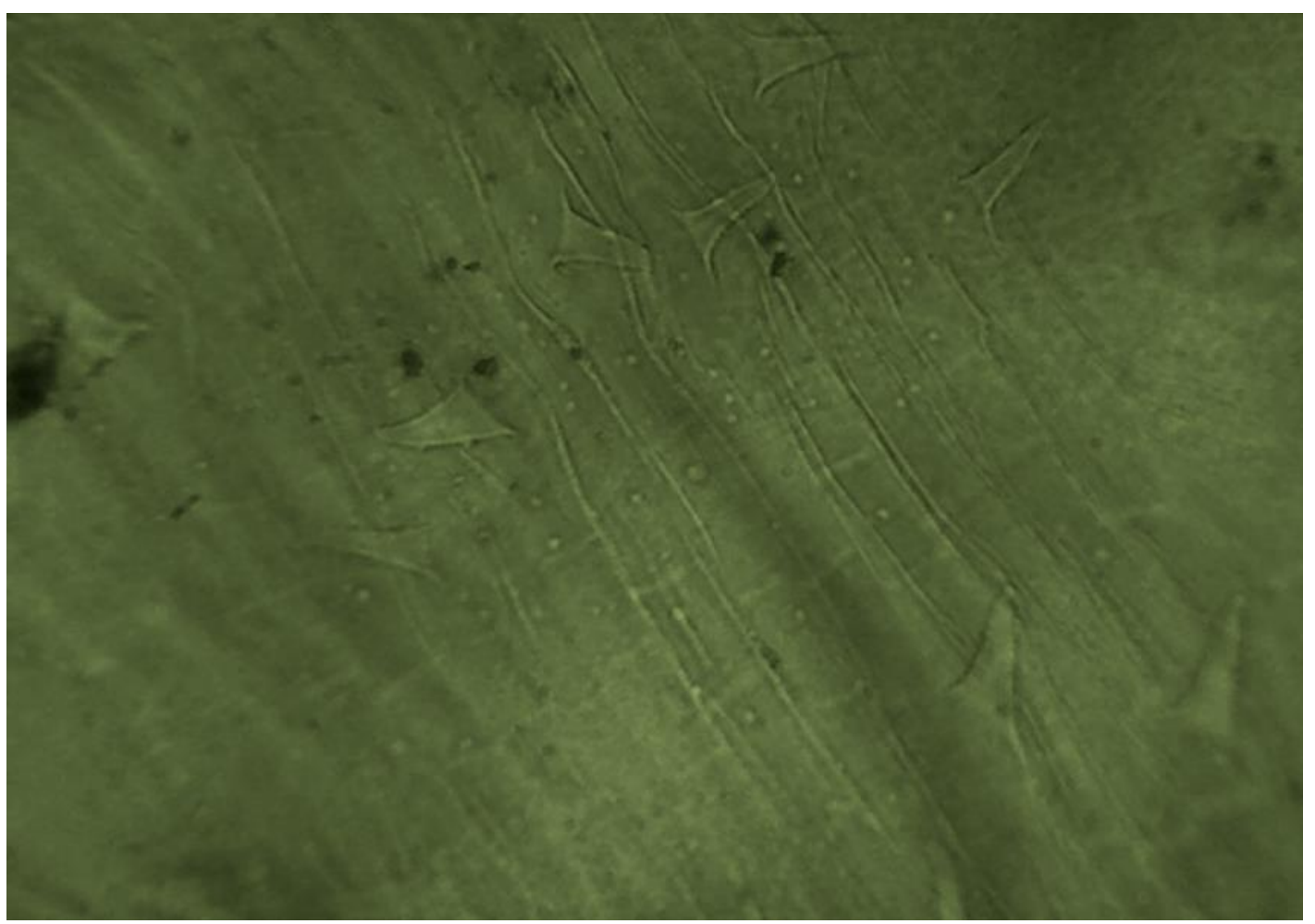

Figure 5: Photomicrograph of the sectional view of the transverse section of Morinda lucida showing phloem parenchyma with short papillose trichomes

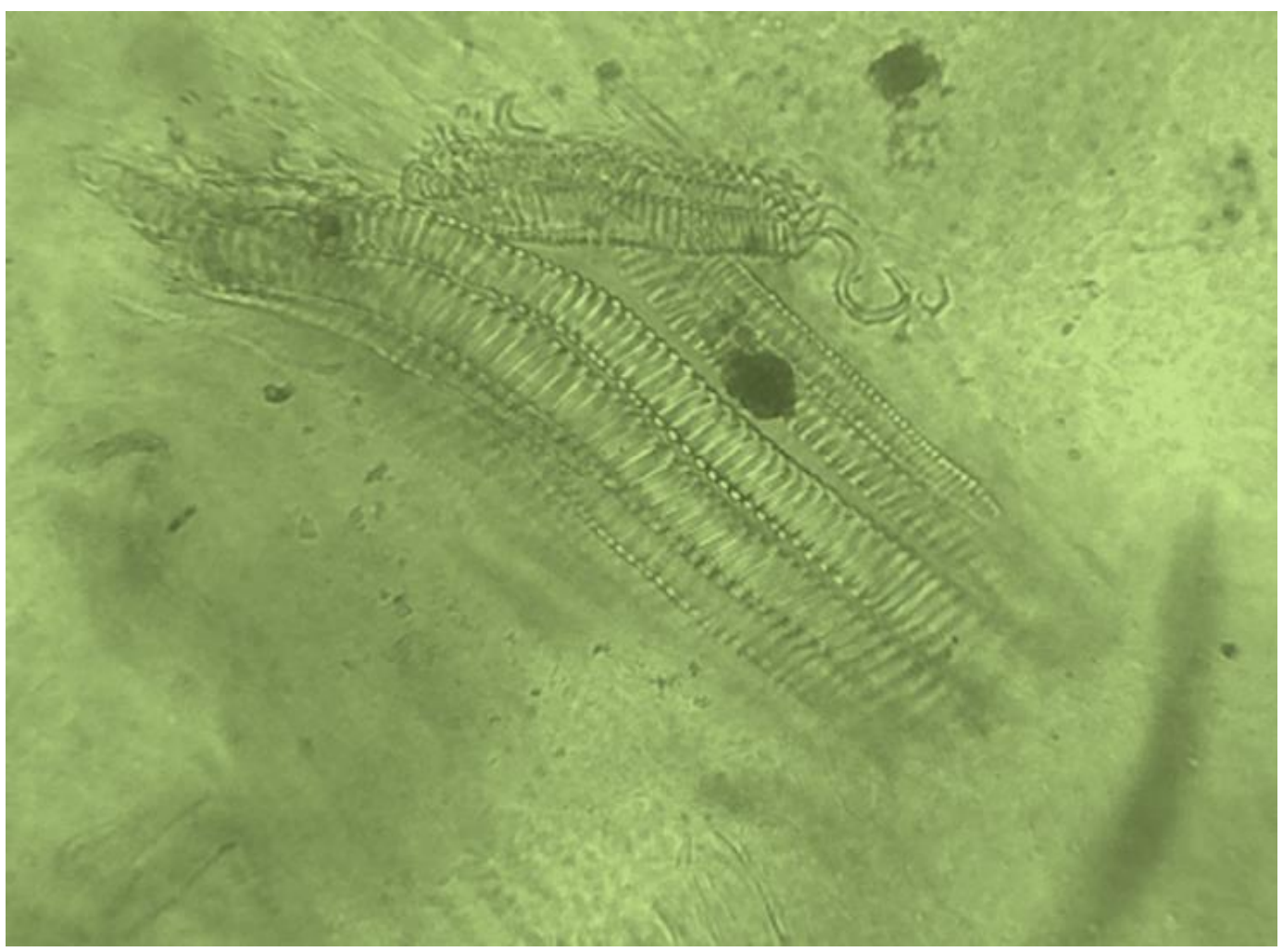

Figure 6: Photomicrograph of the sectional view of the transverse section of Morinda lucida showing spiral xylem vessels 


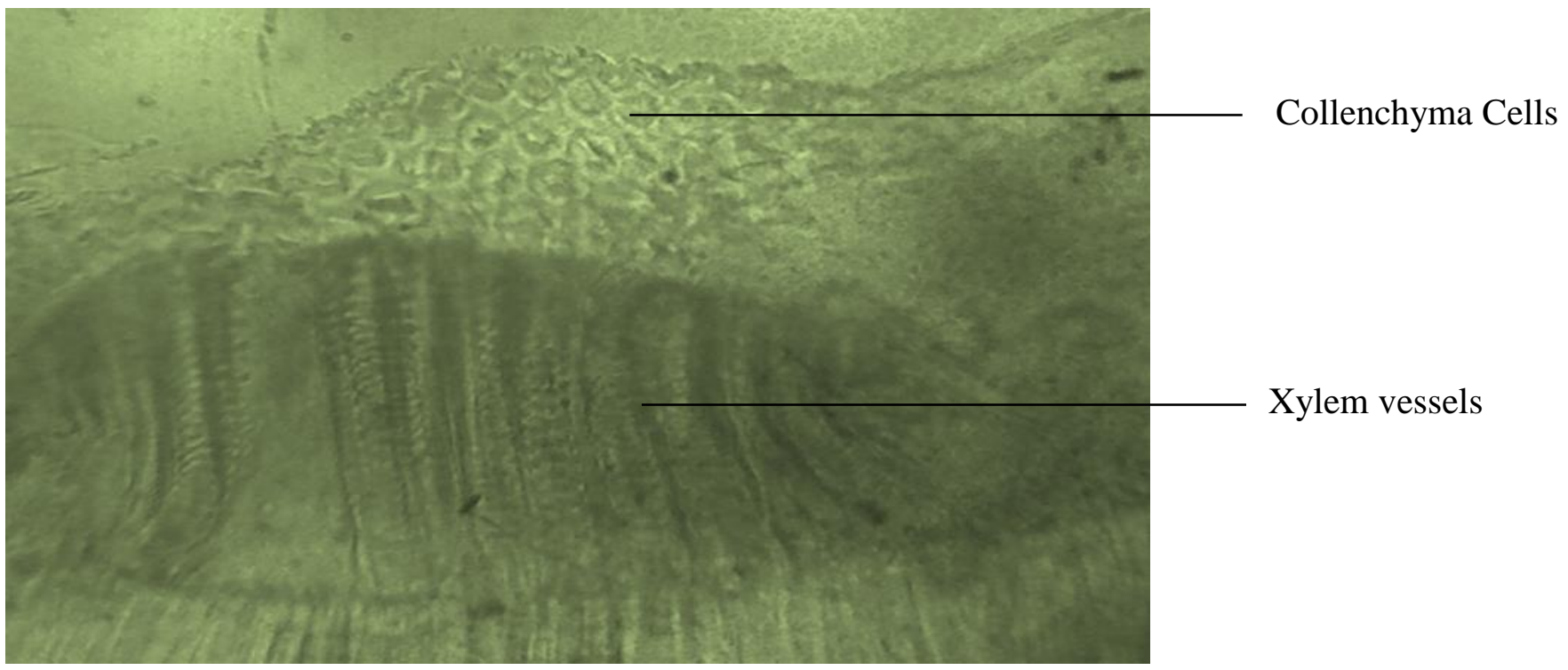

Figure 7: Photomicrograph of the sectional view of the transverse section of Morinda lucida showing phloem, xylem and collenchyma cells

Microscopy of the powdered leaf

The microscopy of the powdered leaf revealed straight epidermal cells with bundle of scalariform xylem vessels, oil droplets, lignified fibres, and bundles of acicular calcium oxalates. There is also presence of unicellular clothing trichomes, diamond and prism shaped calcium oxalates (Figure 8-12).

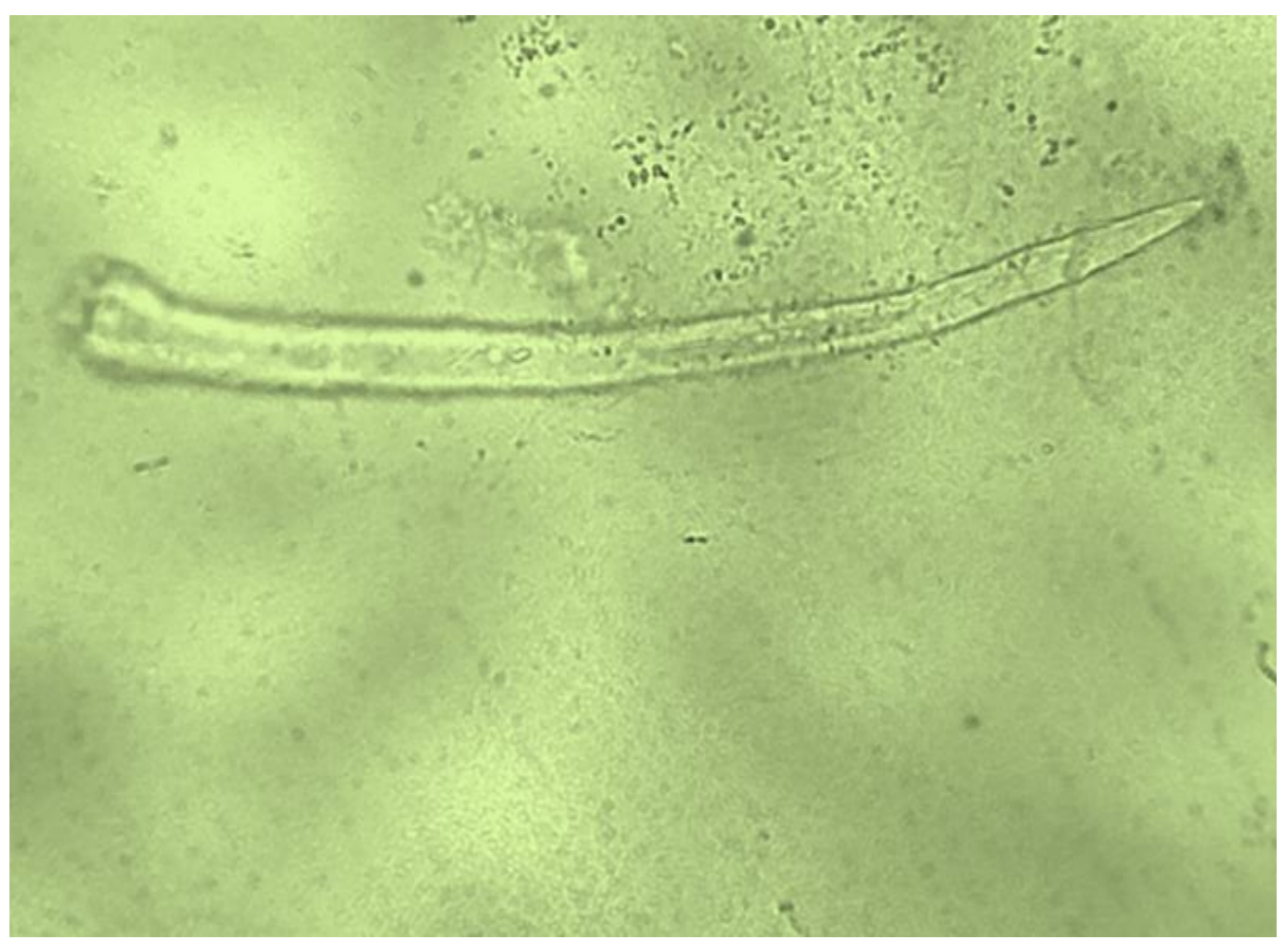

Figure 8: Photomicrograph of microscopy of the powdered leaf of Morinda lucida showing unicellular clothing trichome 


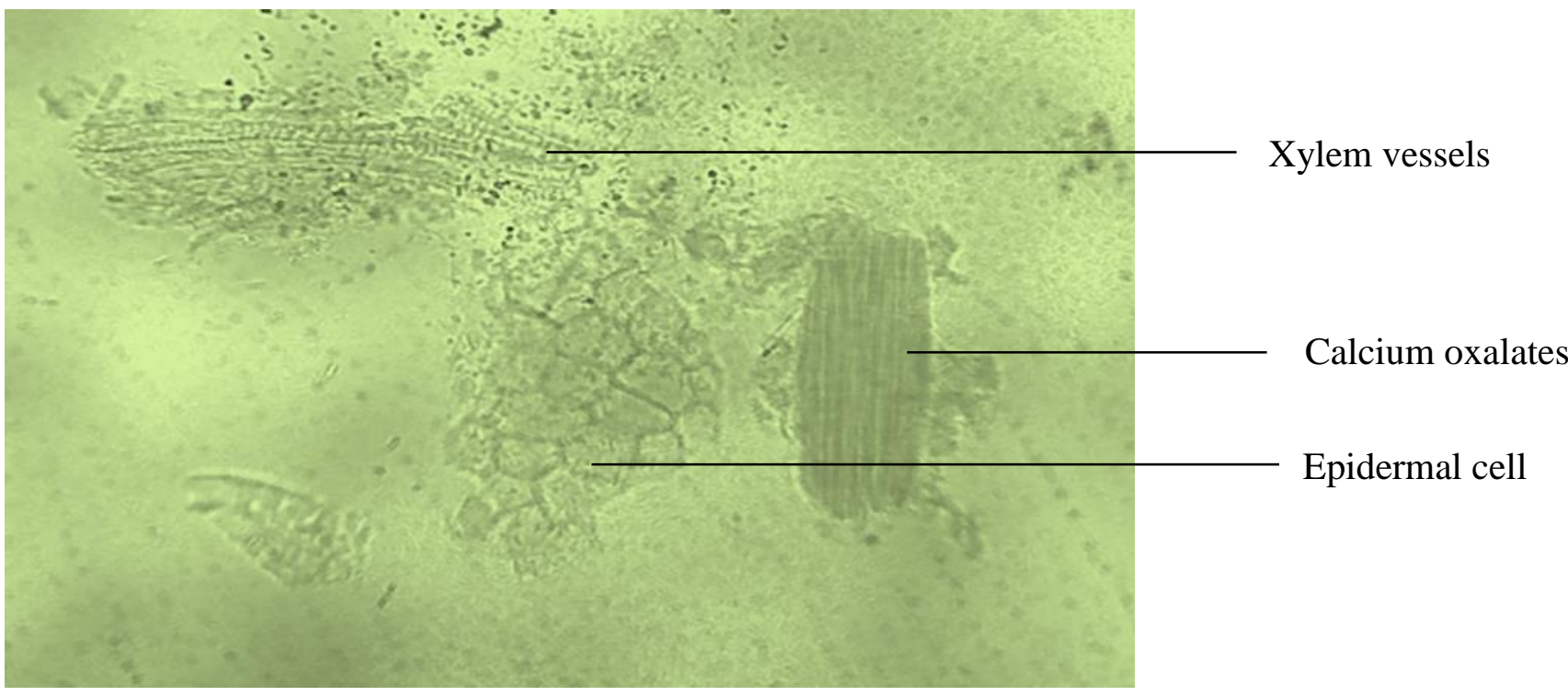

Figure 9: Photomicrograph of microscopy of the powdered leaf of Morinda lucida showing straight epidermal cells, bundle of xylem vessels and bundle of acicular calcium oxalates

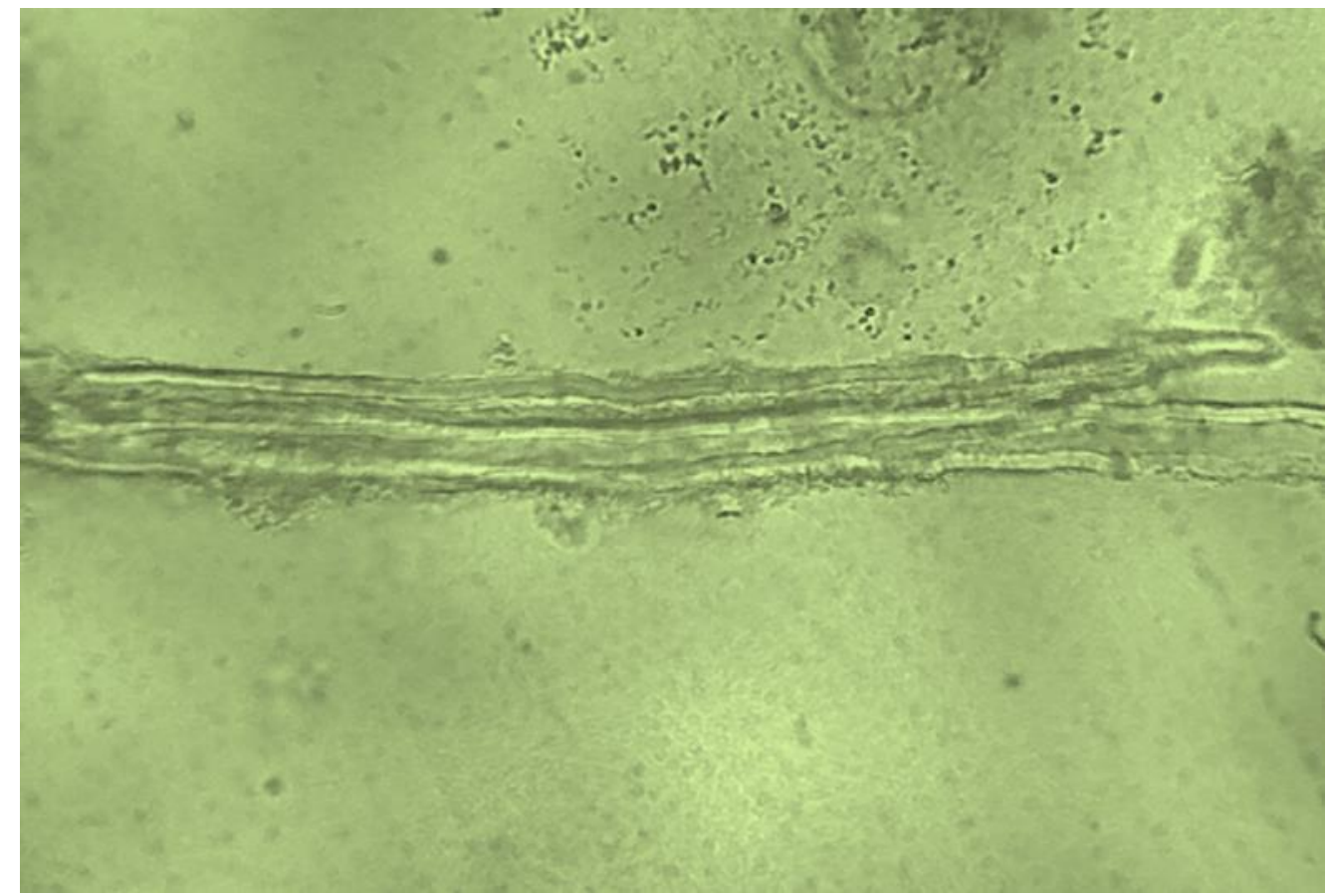

Figure 10: Photomicrograph of microscopy of the powdered leaf of Morinda lucida showing set of fibres with wide lumen. 


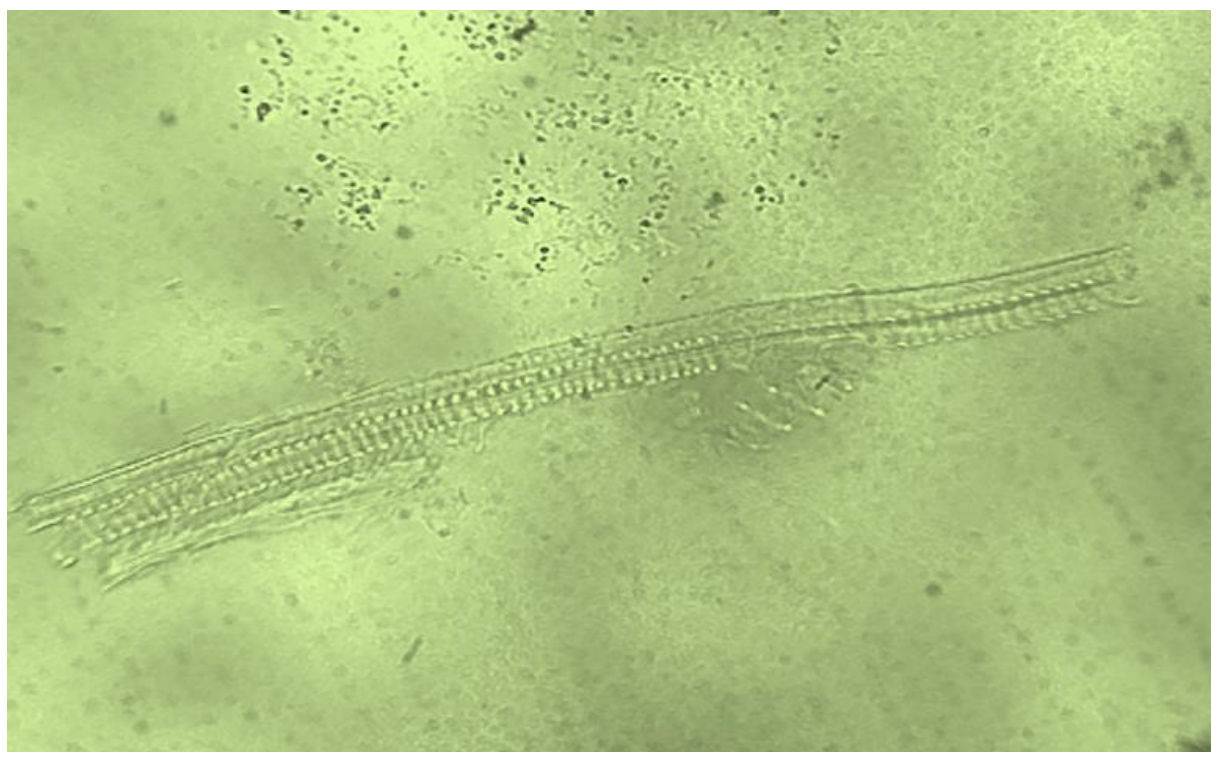

Plate 11: Photomicrograph of microscopy of the powdered leaf of Morinda lucida showing fractured spiral xylem vessels

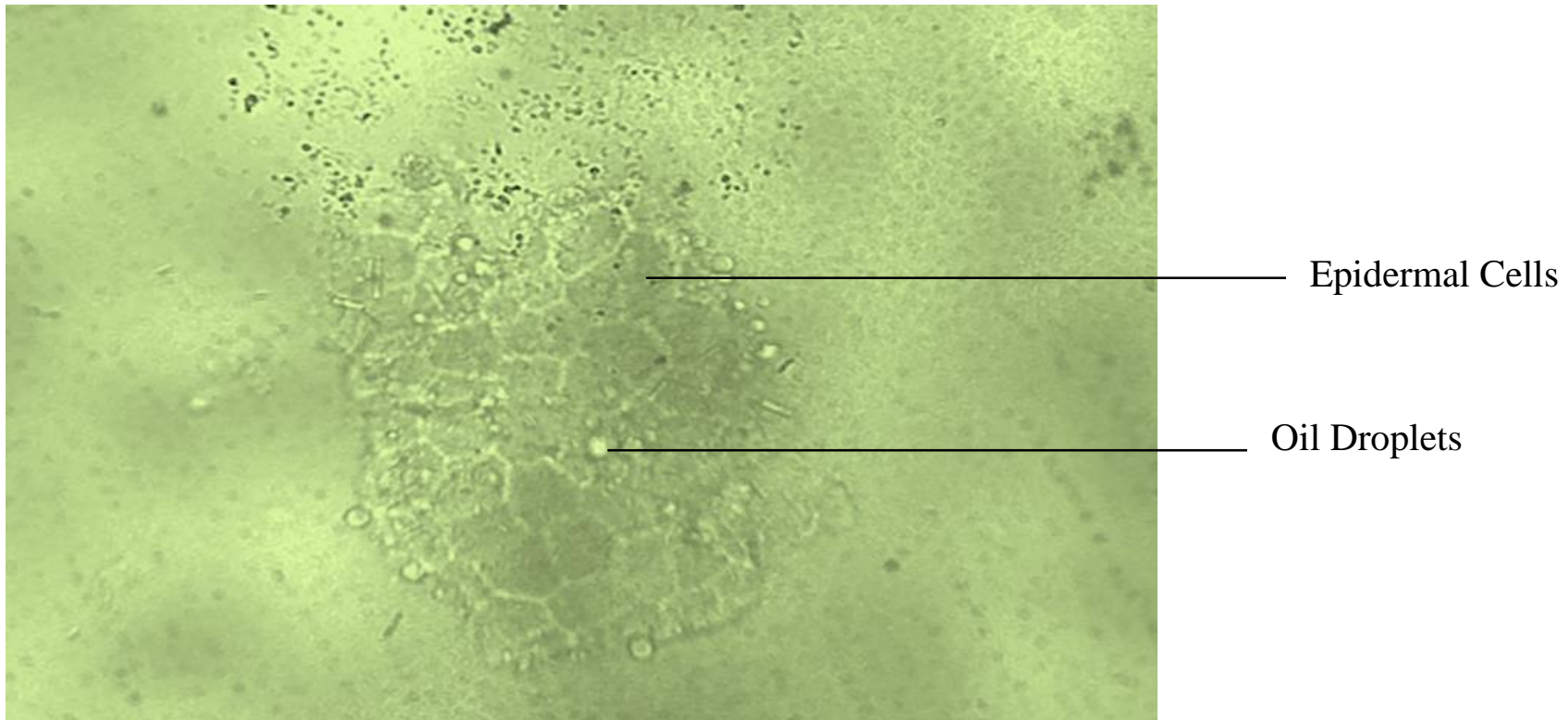

Figure 12: Photomicrograph of microscopy of the powdered leaf of Morinda lucida showing epidermal cells with oil droplets

\section{Results of Analytical Standards}

The ash values reveal the percentage yield and this can be used for detection of adulterants (Table 2).

Table 2: The results of numerical standards

\begin{tabular}{ll}
\hline Numerical standard & Composition ( \% ) \\
\hline Total ash & 8.50 \\
Acid insoluble ash & 1.00 \\
Water soluble ash & 2.00 \\
Sulphated ash & 6.50 \\
Water soluble extractive yield & 6.00 \\
Alcohol soluble extractive yield & 3.40 \\
Moisture content & 11.00 \\
\hline
\end{tabular}


Values are \pm SEM, $n=5$

\section{In vivo pharmacological studies}

\section{Acute toxicity test}

The extract was found to be safe and no toxic effect was observed even at higher doses of $5000 \mathrm{mg} / \mathrm{kg}$, p.o.

\section{Effects of the extract on pentylenetetrazole-induced convulsion}

The seizure latency was prolonged by all the test groups as compared to vehicle treated mice. The percentage protection afforded increased at all dose levels of extracts (200, 400 and 800 $\mathrm{mg} / \mathrm{kg}$, p.o.), whereas the duration of tonic flexion and clonus of the test groups were significantly $(\mathrm{p}<0.05)$ lowered at all dose levels (Table 3$)$. Maximum protection was achieved with diazepam $(0.5 \mathrm{mg} / \mathrm{kg}$, i.p. $)$.

Table 3: Mean values of Effect of extract on Pentylenetetrazole-induced convulsion

\begin{tabular}{|c|c|c|c|c|c|c|c|}
\hline Treatment & $\begin{array}{c}\text { Dose } \\
(\mathrm{mg} / \mathrm{kg})\end{array}$ & $\begin{array}{l}\text { Seizure } \\
\text { onset } \\
\text { (min } \\
\pm \text { SEM) }\end{array}$ & $\begin{array}{l}\begin{array}{l}\text { Peak of } \\
\text { seizure } \\
(\min \end{array} \\
\pm \mathrm{SEM})\end{array}$ & $\begin{array}{l}\text { Recovery } \\
(\min \\
\pm \mathrm{SEM})\end{array}$ & $\begin{array}{l}\text { Mortality } \\
(\min \\
\pm \text { SEM) }\end{array}$ & $\begin{array}{l}\text { \% Animal } \\
\text { exhibiting } \\
\text { convulsion }\end{array}$ & $\begin{array}{l}\% \\
\text { Animal } \\
\text { survival }\end{array}$ \\
\hline $\begin{array}{l}\text { Control } \\
\left(\mathrm{DH}_{2} \mathrm{O}\right) \\
(5 \mathrm{ml} / \mathrm{kg})\end{array}$ & - & $1.49 \pm 0.10$ & $5.03 \pm 0.11$ & $0.00 \pm 0.00$ & $7.93 \pm 0.18$ & 100 & 0 \\
\hline Diazepam & 0.5 & $0.00 \pm 0.00$ & $0.00 \pm 0.00$ & $0.00 \pm 0.00$ & $0.00 \pm 0.00$ & 0 & 100 \\
\hline \multirow[t]{3}{*}{ Extract } & 200 & $4.98 \pm 0.09$ & $6.64 \pm 0.18$ & $31.85 \pm 7.79$ & $16.92 \pm 4.15$ & 100 & 60 \\
\hline & 400 & $5.19 \pm 0.09$ & $6.98 \pm 0.10$ & $25.00 \pm 6.13^{*}$ & $24.63 \pm 6.11$ & 100 & 40 \\
\hline & 800 & $10.01 \pm 0.11$ & $25.01 \pm 0.83$ & $34.96 \pm 8.57$ * & $28.95 \pm 7.17$ & 100 & 60 \\
\hline
\end{tabular}

Values are expressed as the mean \pm SEM of five observations. $*$ The mean difference is significant at $\mathrm{P}<0.05$ (One-way ANOVA followed by Dunnet's post-hoc test). SEM: Standard error of mean.

\section{Effects of the extract on isoniazid-induced convulsion}

Isoniazid (250 mg/kg p.o.) elicited several episodes of tonic-conic convulsions followed mortality in mice. Mice treated with extracts $(200,400$ and $800 \mathrm{mg})$ significantly delayed in the occurrence of seizure as shown in the results in the Table 4. The time of onset, peak of convulsion and death of extracts and diazepam treated mice showed significant delay in occurrence of convulsion and mortality compared to INH control mice. The result showed a dose response relationship as the delay increase as the dose of extracts increases for the onset, peak and mortality as no dose of extract gave recovery. 
Table 4: Mean values of Effect of extract on Isoniazid-induced convulsion

\begin{tabular}{llllllll}
\hline $\begin{array}{l}\text { Treatme } \\
\text { nt }\end{array}$ & $\begin{array}{l}\text { Dose } \\
(\mathbf{m g} / \mathbf{k g})\end{array}$ & $\begin{array}{l}\text { Seizure } \\
\text { onset } \\
(\mathrm{min} \pm \mathrm{SEM})\end{array}$ & $\begin{array}{l}\text { Peak } \\
\text { seizure } \\
(\mathrm{min} \pm \mathrm{SEM})\end{array}$ & $\begin{array}{l}\text { of } \\
(\mathrm{min} \pm \mathrm{SEM})\end{array}$ & $\begin{array}{l}\text { Recovery } \\
(\mathrm{min} \pm \mathrm{SEM})\end{array}$ & $\begin{array}{l}\text { \% Animal } \\
\text { exhibiting } \\
\text { convulsion }\end{array}$ & $\begin{array}{l}\text { \% } \\
\text { Anim } \\
\text { al } \\
\text { survi } \\
\text { val }\end{array}$ \\
\hline $\begin{array}{l}\mathrm{Control} \\
\left(\mathrm{DH}{ }_{2} \mathrm{O}\right)\end{array}$ & - & $39.16 \pm 1.09$ & $40.38 \pm 0.97$ & $0.00 \pm 0.00$ & $45.84 \pm 1.23$ & 100 & 0 \\
$(5 \mathrm{ml} / \mathrm{kg})$ & & & & & & & \\
Diazepam & 0.5 & $82.81 \pm 0.79$ & $96.13 \pm 0.64^{*}$ & $114.00 \pm 27.93$ & $124.77 \pm 30.56$ & 100 & 60 \\
Extract & 200 & $51.52 \pm 0.54$ & $57.40 \pm 0.57^{*}$ & $0.00 \pm 0.00$ & $61.44 \pm 0.83$ & 100 & 0 \\
& 400 & $53.29 \pm 1.92$ & $61.05 \pm 0.98^{*}$ & $0.00 \pm 0.00$ & $86.37 \pm 1.05$ & 100 & 0 \\
& 800 & $64.84 \pm 0.89$ & $80.86 \pm 1.35^{*}$ & $0.00 \pm 0.00$ & $95.53 \pm 0.56$ & 100 & 0 \\
\hline
\end{tabular}

Values are expressed as the mean \pm SEM of five observations. *The mean difference is significant at $\mathrm{P}<0.05$ (One-way ANOVA followed by Dunnet's post-hoc test). SEM: Standard error of mean.

\section{DISCUSSION}

The characteristic features associated with Morinda lucida have been determined by proper identification and evaluation of the plant material provided through various analysis and tests performed.

The phytochemical tests revealed the various chemical constituents of the leaf of Morinda lucida to contain carbohydrates, reducing sugars, glycosides, flavonoids, proteins, tannins, steroids, terpenoids, and resins. The anticonvulsant activity of $M$. lucida may be attributed to the presence of these compounds which have been found in phytochemical investigation of the methanol extract of the plant. It is important to note that, in other studies, plant triterpenoids evaluated for anticonvulsant activity against PTZ-induced convulsion in mice protected $10-40 \%$ of the animals It is possible, therefore, that saponins, which may be of triterpenoid type and the triterpene steroid present in $M$. lucida might contribute to the anticonvulsant activity of the plant species. Previous studies have also demonstrated that some alkaloids have anticonvulsant activity $[4 ; 52]$.

The macroscopic analysis of the plant was carried out by observation of the physical appearance of the plant. Although, this form of analysis cannot be relied upon for proper identification of the plant, it is used mainly to describe the morphological parts of the plant.

The microscopic analysis is carried out to determine and analyze the different minute characteristic features of the leaf and features of the transverse section of the leaf. A few microscopic features showed the presence of epidermal cells, unicellular trichomes, bundle of fibres, anomocytic type of stomata, palisade cells, collenchyma cells, spiral xylem, phloem and acicular calcium oxalates. 
The ash values reveal the percentage yield and this can be used for detection of adulterants, this is done to meet up the British Pharmacopoeia requirement. Total ash value is a diagnostic purity index; it represents both physiological ash and non-physiological ash [53]. Physiological ash is derived from plant tissues due to biochemical processes while nonphysiological ash consists of residue of the extraneous matter (such as sand, soil, etc.) adhering to plant samples itself [54]. Physiological ash gets dissolved in the dilute acid while some of the non-physiological ash remains undissolved [54]. Carbonates, phosphates, nitrates, sulphates, chlorides and silicates of various metals which were taken up from the soil or environment constitute total ash [55]. Acid-insoluble ash is a part of total ash and measures the amount of silica present, especially as sand and siliceous earth in the samples. Lower and higher value of acid insoluble ash content indicates the magnitude of presence of oxalates, carbonates, phosphates, oxides and silicates respectively. Thus $1.00 \%$ of acid insoluble ash in M. lucida is indicative of the presence of high content of oxalates, carbonates, phosphates and oxides while low content of silicates [53]. Water soluble ash (2.00\%) content gives the crude estimate of the water soluble extractable matter present in the ash [56]. If the aqueous extract of crude shows biological activity the role of water soluble ash value is important.

The results of the anticonvulsant studies of methanol extract of Morinda lucida revealed that treatment with the extract protected against PTZ and isoniazid - induced convulsions and mortality. In PTZ and isoniazid induced seizures, the extract at 200, 400, and $800 \mathrm{mg} / \mathrm{kg}$, p.o. caused a significant increase in the latency to convulsions and also in the latency to death when compared with control, demonstrating a protective effect.

The etiology of epilepsy may probably be due to an imbalance in the brain between inhibitory neurotransmission mediated by the major inhibitory neurotransmitter, gamma aminobutyric acid (GABA) and excitatory neurotransmission mediated mainly by glutamate $57 ; 58 ; 4]$.

Pentylenetetrazole produced tonic seizures in all the animals used with the exception of the group treated with diazepam. The convulsing mechanism of PTZ is poorly understood, but it is reported that this substance is able to inhibit chloride conductance by binding to sites of $\mathrm{GABA}_{\mathrm{A}}$ receptor complex [59] and thereby inhibiting GABA neurotransmission at $\mathrm{GABA}_{\mathrm{A}}$ receptors in the brain [60;4]. A dose of $200 \mathrm{mg} / \mathrm{kg}$ methanol extract of Morinda lucida protected $60 \%$ of animals that survived after convulsion and this dose also prolonged the onset, peak of seizures to a significant extent before either recovery or mortality which was also prolonged. Extract at doses of 400 and $800 \mathrm{mg} / \mathrm{kg}$ significantly delayed the latency of the seizures and also gave 40 and $60 \%$ of mice survival respectively. The standard antiepileptic drug, diazepam has been shown to produce their antiepileptic effect by enhancing GABA neurotransmission in the brain (Rang et al., 2007). And from the result, diazepam completely protected the animals from seizures and it gave $100 \%$ mice survival. The attenuation of PTZ- 
induced seizures by diazepam in this study may probably be due to their enhancement of GABA neurotransmission. In the above discussed result from the statistical analysis can be said to have a dose dependent relationship. The time of onset, recovery and mortality of seizure for $200 \mathrm{mg} / \mathrm{kg}$ is as follows; 4.98, 31.85 and $16.92 \mathrm{~min}$ when compared to $400 \mathrm{mg} / \mathrm{kg}$ $(5.19,25.00,24.63 \mathrm{~min})$ and $800 \mathrm{mg} / \mathrm{kg}(10.01,34.96,28.95 \mathrm{~min})$ can said to have increased latency to seizure onset, recovery and mortality. The $800 \mathrm{mg}$ gave a significant delay in the peak of seizure (25.01 min) about 15 min delay was observed.

In INH-induced seizure, methanol extract of M. lucida in doses of 200, 400 and $800 \mathrm{mg} / \mathrm{kg}$ were found to be significantly active as they showed significant latency to convulsions and also in the latency to death when compared with control. The order of activity was $200>400$ $>800 \mathrm{mg} / \mathrm{kg}$ in terms of the delay observed in the onset of seizure, peak and mortality. This may be because of the fact that $800 \mathrm{mg} / \mathrm{kg}$ gave a greater latency in onset, peak and even mortality as all the doses of extract gave $100 \%$ mortality and $0 \%$ recovery. From the result obtained for time of onset of seizure and mortality from the statistical analysis, $200 \mathrm{mg}$ gave 51.52 and $61.00 \mathrm{~min}, 400 \mathrm{mg}$ also gave 53.29 and $86.37 \mathrm{~min}$ and $800 \mathrm{mg} / \mathrm{kg}$ gave 64.84 and 95.53 min respectively. From this result it can be seen that there was increased delay as the dose of the extract increases, so to delay or prevent the seizure that can lead to mortality that after an hour there should be another administration of the extract. Diazepam was also used as the standard drug; it significantly affected the onset, peak of incidence convulsion and gave a $60 \%$ animal survival as shown in Table 4. Isoniazid- induced convulsion are used to determine the activity of compounds absence or petit mal seizures $[61 ; 62]$, therefore the extract can be said to have activity on INH-induced seizure.

\section{CONCLUSION}

The results obtained from the phytochemical analysis gives a clear indication that the plant is rich in many secondary metabolites and this can be linked to its numerous medicinal effects. The quality standards established will assist in proper identification and detecting adulterants. The methanol extract of Morinda lucida has exhibited anticonvulsant effect in line with its ethnomedicinal use but the mechanism of its effect is unknown at this stage of work. Also the bioactive constituent responsible for this activity is not precisely known.

\section{RECOMMENDATION}

It is however, recommended that more work should be done for the isolation, identification and establishment of the active constituent(s) and also to elucidate the mechanism of action as this plant hold great potential for new anticonvulsant drug development.

\section{REFERENCES}

1. S. Sahu, G. Dutta, I. N. Manda, A.R. Goswami, T. Ghosh, Anticonvulsant effect of 
Marsilea quadrifolia Linn. on pentylenetetrazole induced seizure: A behavioral and EEG study in rats. J Ethnopharmacol. 141 (1):537-41 (2012).

2. W. A. Hauser, J. F. Anneger, Epidemiology of Epilepsy. In Laidlam J. Richen A and Chadwick D. Ed. Textbook of epilepsy. Churchill Livingstone: Edinburgh. 23-45, (1993).

3. W. A. Hauser, J. F. Annegers, L. T. Kurland, Prevalence of epilepsy in Rochester, Minnesota: 1940-1980. Epilepsia; 32:429-445, (1991).

4. H. P. Rang, M. M. Dale, J. M. Ritter, R. J. Flower, Rang and Dale's Pharmacology. 6th ed. Amsterdam, New York: Elsevier, (2007).

5. A. Mandegary, M. Arab-Nozari, H. Ramiar, F. Sharififar, Anticonvulsant activity of the essential oil and methanolic extract of Bunium persicum (Boiss). B. Fedtsch. J Ethnopharmacol; 140(2):447- 451, (2012).

6. C. N. Aguwa, U. Ochei, Epilepsy. In: therapeutic Basis of Clinical Pharmacy in the Tropics. $2^{\text {nd }}$ edn. (Aguwa, C. N. Ed). Optimal Publishers, Enugu, Nigeria 1990. p. 333-347, (1996)..

7. J. Engel,Jr, Surgical Treatment of the Epilepsies. 2nd ed. New York: Raven Press; (1993).

8. W.B. Matuja, H.T. Rwiza, Knowledge, Attitude and Practice (KAP) towards epilepsy in secondary school students in Tanzania. Cent. Afr J. Med., 40: 13-18, (1994).

9. A. Millogo, V. Ratsimbazafy, P. Nubukpo, S. Barro, I. Zongo,P. M. Preux, Epilepsy and traditional medicine in bobo-dioulasso (Burkina Faso). Acta Neurol. Scand., 109(4):250-254, (2004).

10. E. B. F. Ngounou, C. M. Quet, B. Dubreuil, D. Marin, P. Houinato, F. Nubukpo, A. Dalmay, G. Millogo, P. Nsengiyumva, M. Kouna-Ndouongo, V. Diagana, M. Ratsimbazafy, Druet-Cabanac, P.M. Preux, Epidemiology of epilepsy in subsaharanAfrica. J. Stud. Res. (French), 16(4):225-238 (2007).

11. N. Senanayake, G.C. Roman, Epidemiologyof epilepsy in developing countries. Bull. W.H.O., 71: 247- 258 (1993)..

12. U. Heinemann, A. Draguhn, E. Ficker, J. Stabel, C.L. Zhang, Strategies for the development of drug for pharmaco resistant epilepsies. Epilepsia, 35:S10-S21 (1994).

13. S. D. Shorvon, The epidemiology and treatment of chronic and refractory epilepsy. Epilepsia, 37:S1-S3(1996).

14. O. Devinsky, Cognitive and behavioural effects of antiepileptic drugs. Epilepsia, 36: S46-S65 (1995)..

15. R. H. Mattson, Efficacy and adverse effects of established and new antiepileptic drugs. Epilepsia, 36(2): S13-S2 (1995).. 
16. A. Millogo, V. Ratsimbazafy, P. Nubukpo, S. Barro, I. Zongo, P.M. Preux, Epilepsy and traditional medicine in bobo-dioulasso (Burkina Faso). Acta Neurol. Scand., 109(4):250-254 (2004).

17. P. M. Preux, M. Druet-Cabanac, Epidemiology and aetiology of epilepsy in subSaharan Africa. Lancet Neurol., 4 (1):21-31(2005).

18. E.B., F. Ngounou, C.M. Quet, B. Dubreuil, D. Marin, P. Houinato, F. Nubukpo, A. Dalmay, G. Millogo, P. Nsengiyumva, M. Kouna-Ndouongo, V. Diagana, M. Ratsimbazafy, Druet-Cabanac, P. M. Preux, Epidemiology of epilepsy in subsaharanAfrica. J. Stud. Res. (French), 16(4):225-238 (2007).

19. Jawed, Ali Quazi, Evaluation of possible anticonvulsant effect of Alstonia scholaris (Linn.) R. br. extract on epilepsy models Asian Journal of Pharmaceutical and Clinical Research. 8(3): 207-209 (2015).

20. A. B. Doney, P. Nisha, S. K. Dona, J. Jamsy, S. J. Tintu, D. Amal, Evaluation of anticonvulsant activity of Premna corymbosa in experimental mice. International Journal of Experimental Pharmacology, Vol. 1, 37-41 (2011)..

21. G. J. Amabeoku, Anticonvulsant activity of Nylandtia spinosa L. Dumont (Polygalaceae) aqueous and methanol leaf extracts in mice. Hum Exp Toxicol.27:811818 (2008).

22. C. S. Ravindra, B. K. Sanjay, V. K. Kalaichelvan, Evaluation of Anticonvulsant Activity of Leaf Extracts of Holoptelea Integrifolia (Roxb.) Planch in Experimental Animals International Journal of Pharmacy and Pharmaceutical Sciences ISSN- 09751491 Vol 6, (2014).

23. Okokon, D. Koofreh, Psychopharmacological Studies of Homalium letestui Stem Extracts Journal of pharmaceutical Biology,4(3) :158-164 (2014)..

24. A. Konate, W. R. Sawadogo, F. Dubruc, O. Caillard, M. Ouedraogo, I.P. Guissou, Phytochemical and Anticonvulsant Properties of Annona senegalensis Pers. (Annonaceae), Plant Used in Burkina Folk Medicine to Treat Epilepsy and Convulsions. British Journal of Pharmacology and Toxicology 3(5): 245-250 (2012).

25. L. J. Quintans-junior, T. T. Souza, B. S. Leite, M. N. Lessa,L. R. Bonjardim, M. R. Santos, P. B. Alves, A. F. Blank, A. R. Antoniolli, Phytochemical screening and anticonvulsant activity of Cymbopogon winterianus Jowitt ( Poaceae) leaf essential oils in rodents. Phytomedicine, 15,619 - 624 (2008)..

26. A. Manigauha, S. Patel, J. Monga, H. Ali, Evaluation of anticonvulsant activity of Pongamia pinnata in experimental animals. Int J Pharmatech Res.1(4):1119-1121 (2009). 
27. L. S. Gill, Ethnomedicinal Uses of Plants in Nigeria. Uniben Press, Benin City, Nigeria, (1992).

28. N. E. Nweze, In vitro anti-trypanosomal activity of Morinda lucida leaves, African Journal of Biotechnology 11(7): 1812-1817 (2011).

29. J. M. Dalziel, The Useful Plants of West Tropical Africa. $1^{\text {st }}$ Edn., Crown Agents for the Colonies. London. 403-404 (1937).

30. G. A. Adesida, E. K. Aesogan, Oruwal, a novel dihydroanthraquinone pigment from Morinda lucida Benth. J. Chem. Society: Chemical Communications 1:405-406 (1972).

31. A. A. Odutuga, J. O. Dairo, J. B. Minari, F. A. Bamisaye, Anti-Diabetic Effect of Morinda lucida Stem Bark Extracts on Alloxan-induced Diabetic Rats. Res. J. Pharmacol. 4(3): 78-82 (2010).

32. C. Zimudzi, D. Cardon, Morinda lucida Benth; [Internet] Record from Protabase. PROTA (Plant Resources of Tropical Africa/Resources végétales de l'Afrique tropicale), Wageningen, Netherlands, Accessed 29th October, 2011, (2005). <http://database.prota.org/search.htm>.

33. G. A. Agbor, P. A. Tarkang, J. V. Z. Fogha, L. F. Biyiti, V. Tamze, H. M. Messi, N. Tsabang, F. Longo, A. T. Tchinda, B. Dongmo, N. T. Donfagsiteli, J. N. Mbing, K. Joseph, R. A. Ngide, D. Simo, Acute and Subacute Toxicity studies of Aqueous Extract of Morinda lucida Stem Bark, Journal of Pharmacology and Toxicology, $7: 158-165(2012)$,

34. J. M. Makinde, P. O. Obih, Screening of Morinda lucida leaf extract for antimalarial action on Plasmodium berghei berghei in mice. Afr. J. Med. Med. Sci., 14(1-2): 59-63 (1985).

35. I. U. Asuzu, C. N. Chineme, Effects of Morinda lucida leaf extract on Trypanosoma brucei brucei infection in mice. J Ethnopharmacol., 30(3): 307-313 (1990).

36. A. A. Sowemimo, F. A. Fakoya, I. Awopetu, O. R. Omobuwajo, S. A. Adesanya, Toxicity and Mutagenic activity of some selected Nigerian plants. J. Ethnopharmacol., 113:427-432 (2007).

37. T. Oduola T., I. Bello, G. Adeosun, A. Ademosun, G. Raheem, G. Avwioro, Hepatotoxicity and nephrotoxicity evaluation in Wistar albino rats exposed to Morinda lucida leaf extract. NAJ. Med. Sci. 2: 230-233 (2010).

38. Y. Raji, O. S. Akinonmisoye, T. M. Salman, Antispermatogenic activity of Morinda lucida extractin male rats . Asian J. Andol., 7:405-410 (2005) 
39. O. P. Adomi, E. G. Umukoro, Antibacterial activity of aqueous and ethanol crude extracts of the root barks of Alstonia boonei and preliminary phytochemical test of Morinda lucida; Journal of Medicinal Plants Research Vol. 4(8), 644-648 (2010).

40. L. Tona, N. P. Ngimbi, M. Tsakala, K. Mesia, K. Cimanga, S. Apers, T. De Bruyne, L. Pieters, J. Totte, A. J. Vlietinck, Antimalarial activity of 20 crude extract from nine African medicinal plants used in Kinshasa, Congo. J. T., Ethnopharmacol. 68 (13): 193-203 (1999).

41. P. U. Agomo, J. C. Idigo, B. M. Afolabi, Antimalarial" medicinal plants and their impact on cell populations in various organs of mice. Afr. J. Med. Sci., 21(2): 39-46 (1992).

42. K. Koumaglo, M. Gbeassor, O. Nikabu, C. De Souza, W. Werner, Effects of three compounds extracted from Morinda lucida on Plasmodium falciparum. Planta Med., 58(6): 533-544 (1992).

43. O. E. Ogunlana, O. Ogunlana, O. E. Farombi, Morinda Lucida: Antioxidant and Reducing Activities of Crude Methanolic Stem Bark Extract.Adv. in Nat. Appl. Sci., 2(2):49-54 (2008).

44. A. O. Ogundare, A.K. Onifade, The antimicrobial activity of Morinda lucida leaf extract on Escherichia coli. J. Med. Plants Res. 3(4):319-323 (2009).

45. J. B. Harborne, A. J. Harborne, (Eds.) Phytochemical Methods: A Guide to Modern Techniques of Plant Analysis. London:Kluwer Academic Publishers (1998).

46. G. E. Trease, N. C. Evans, Pharmacognosy $13^{\text {th }}$ Ed., Bailliere Tindall, London . 315629 (1989).]U. E. Odoh, C.O. Ezugwu, S. I. Inya-Agha, C. E. C. Ugwuoke, M. Ezejiofor, S. C. Ezea, Techniques in Macroscopical and Microscopical Examinations of Crude Drugs. Paschal Communications, Enugu, Nigeria (2011).]

47. U. E. Odoh, C/ O. Ezugwu CO, Inya-Agha SI, Ugwuoke CEC, Ezejiofor M, Ezea SC. Determination of Pharmacognostic Standards of Medicinal Plants. Paschal Communications, Enugu, Nigeria, 2012.

48. British Pharmacopoeia (1973). Printed in England for Her Majesty`s Stationery office by the University Printing House Cambridge, pp A66.

49. D. Lorke, A new approach to practical acute toxicity testing. Arch. Toxicol., 54:275287 (1983). CrossRef | PubMed | Direct Link |

50. P. A. Akah, A. Sampson, K. Gammaniel, C. Wambebe, Effect of coconut water on the activity of some centrally acting drugs. Indian Drugs, 35:693-695 (1998).

51. E. R. De Almeida, K. R. Rafael, G. B. Couto, A. B. Ishigami, Anxiolytic and anticonvulsant effects on mice of flavonoids, linalool, and alpha-tocopherol presents 
in the extract of leaves of Cissus sicyoides L. (Vitaceae). J Biomed Biotechnol; 2009:274740 (2009).

52. R. H. Shukla, D. Painuly, A. Shukla, V. Kumar, J. Singh, A. Porval, S. Vats, Physical Evaluation, Proximte analysis and Antimicrobial activity of Morus nigra seeds. Int J Pharm Pharma Sci Vol 7(1): 191-197 (2014)

53. E. I. Shellard, Exercises in the evaluation of drugs and surgical dressings $1^{\text {st }}$ ed. Pitman Medical Publishing Co. Ltd. (1958).

54. O. F. Kunle, Phytochemical and microbiological studies of the leaf Lippia multiflora Mold, FAM. Verbanaceae. A Ph.D. dissertation, Ahmadu Bello University, Zaria $(2000$

55. C. K. Kokate, A. P. Purohit, S. B. Gokhale, Pharmacognosy. $42^{\text {nd }}$ ed. Pune India; Nirali Prakashan (2008)

56. S. J. Czuczwar, P.N. Patsalos, The new generation of GABA enhancers, potential therapeutics in the treatment of epilepsy. CNS Drugs, 15:339-350 (2001). | PubMed |

57. D. G. Waller, A. G. Renwick, K. Hillier, Medicinal Pharmacology and Therapeutics. 2nd Edn., Elsevier Saunders, Edinburgh (2005).

58. M. A. Mirski, J. A. Ferrendelli, Interruption of the connections of the mammillary bodies protects against generalized pentylenetetrazol seizures in guinea pigs. J. Neurosci. 7(3):662-70 (1987).

59. A. V. De Sarro, V. Cecchetti, F. Fravolini, O. Naccari, Tabarrini, G. De Sarro, Effects of novel 6-desfluoroquinolones and classic quinolones on pentylenetetrazole-induced seizures in mice. Antimicrob. Agents Chemother.,43:1729-1736 (1999). PubMed | Direct Link |

60. A. Perio, J. P. Chambon, R. Calassi, M. Heaulme, K. Biziere, Evaluation of two anticonvulsant amino-pyridazine derivatives in the conflict test in rats. J. Pharmacol. Exp. Ther., 239(2): 542-547 (1986).

61. S. Sivakumar, N.P. Surendra, P. S. James, G. Suthakar, Anticonvulsant and SedativeHypnotic Activities of N-Acetyl/Methyl Isatin Derivatives. Sci Pharm., 76, 621-636 (2008).

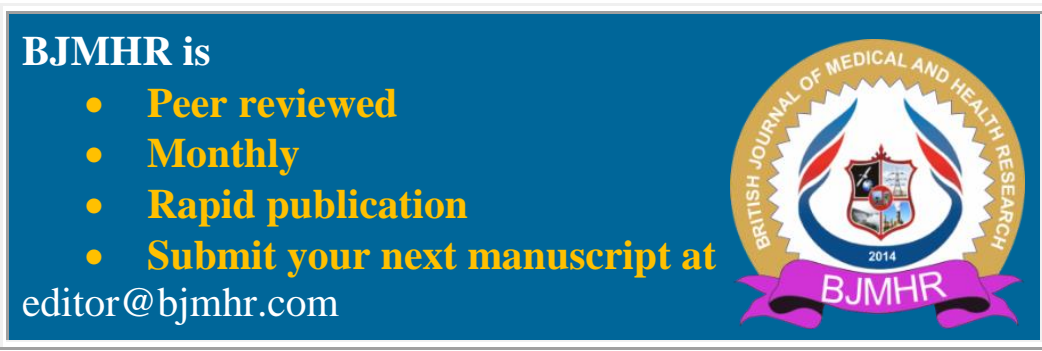

